\title{
Revisiting Vattel's Law of Nations to Discern the Classical Principles of the International Investment Law
}

\author{
Anuj Kumar Vaksha1, Surya Prakash Singh² \\ ${ }^{1}$ University School of Law \& Legal Studies, Guru Gobind Singh Indraprastha University, Delhi, India \\ ${ }^{2}$ Centre for Law and Governance, Central University of South Bihar, Bihar, India \\ Email: anujvaksha@yahoo.com, surya07singh@gmail.com
}

How to cite this paper: Vaksha, A. K., \& Singh, S. P. (2020). Revisiting Vattel's Law of Nations to Discern the Classical Principles of the International Investment Law. Beijing Law Review, 11, 277-291. https://doi.org/10.4236/blr.2020.111019

Received: February 21, 2020

Accepted: March 20, 2020

Published: March 23, 2020

Copyright $\odot 2020$ by author(s) and Scientific Research Publishing Inc. This work is licensed under the Creative Commons Attribution International License (CC BY 4.0).

http://creativecommons.org/licenses/by/4.0/ (c) (i) Open Access

\begin{abstract}
The present paper seeks to examine various issues of the contemporary International Investment Law within the classical international law framework found in Vattel's Law of Nations written in the mid of the eighteenth century. On study it is found that Vattel's work is an enriching source for the natural law principles contextually applicable to the contemporary international investment law. It is found that many of the contemporary international law institutions for protection of foreign investments like the scope and standards for protection of foreign investments, principles of reparation, exhaustion of local remedies, diplomatic protection, treaty based protection for foreign investments, measures for peaceful and coercive dispute resolution etc. can be traced in Vattel's classical work. Contextualization of Vattel's classical work to the contemporary issues of international investment law has the potential to enrich the contemporary literatures and jurisprudence on international investment law, particularly from the perspectives of pragmatic natural law philosophy.
\end{abstract}

\section{Keywords}

Foreign Trade, Foreign Investment, Sovereign, Jurisdiction, Self-Preservation, Denial of Justice, Resolution of Disputes

\section{Introduction: Vattel's Law of Nations}

Emer de Vattel's work titled "Le droit des gens. Ou Principes de la loinaturelle, appliqués àla conduite \& aux affaires des nations \& des souverains", the title translated in English as "The Law of Nations, or Principles of the Law of Nature, 
Applied to the Conduct and Affairs of Nations and Sovereigns", was first published in 1757 in French. Within a century of its first publication as many as twenty French editions were published, besides multiple translations of his work were followed in various European languages by the scholars of Britain, America, Italy, Germany and other scholars. Vattel's work is considered an epoch making exercises and is often said to be commencing a new paradigm in the history of law of nations. Van Vollenhoven divides the history of the law of nations in three different phases each corresponding to a distinct model of international law. The first phase corresponds to the law of nations that originated alongside the modern nation-state in the sixteenth century and was represented by authors such as George Zouche and Cornelius Van Bynkershoek, the second phase corresponded to law of nations that was born in 1757 with Vattel's work and would regulate international conduct until the First World War and the third phase was "at the door" after three hundred years of the publication of Grotius' work in 1625 entitled On the Laws of War and Peace (Van Vollenhoven, 1919). It is the second phase of Law of Nations which Van Vollenhoven refers as the classical international law and its founding principles are found in the Vattel's pioneering work often popularly called Droit des gens that remained a key text, a true classic, in the field of International Law until as late as the early twentieth century (Stapelbroek \& Trampus, 2019). Contributions of Vattel are immense and enduring in the history of the theorization of the Law of Nations. It is comprehensive and the principles enunciated therein cover almost every aspect of International Law. In the specific area of foreign trade, Vattel's book is sprayed with various principles of law which on the one side seem to contest rigorous mercantilism and on the other side create legal basis for protection of foreign traders, merchants and their property in alien nations.

The essence of Vattel's doctrine consists in the reconstruction of the law of nations as a law of states, based on a strictinter-state conception of international society. He conceived the law of nations based on the sovereignty of states and further developed the idea that, in law, sovereign states are at once free and equal, and that it is on this dual legal basis that international law must be founded (Stapelbroek \& Trampus, 2019). Vattel professed that an eternal and immutable law of nature obliged a state not only to respect and to treat other states as equals but also to provide mutual aid so far as that other stands in real need of its assistance, and the former can grant it without neglecting the duties it owes to itself. Around these fundamental principles of law of nations, Vattel wrote his classical work on International Law, touching upon almost every aspect of International relations, politics, trade and war in four different parts (books) of the compendium.

\section{Note on Methodology}

The present paper is based on the English translation of Vattel's French work under the editorship of Béla Kapossy and Richard What more, published in 2008 
(Vattel, 2008 (1758)). In Vattel's complete compendium of four books, the phrases like "foreign investment" or "foreign capital" is not found even once. Term "capital" is found couple of times, but in all instances it has been used in the context of capital punishment or capital crime. However, the terms wealth, money, commerce, trade, foreigner and foreign trade has been used extensively. It is understandable that it is now that the foreign investment or foreign capital have come to acquire a distinct connotation from the term foreign trade; it is premised that whatsoever little flow of foreign capital or foreign investment may have been there during the days of Vattel, conceptually it may be covered by the phrase foreign wealth or wealth of foreign nationals involved in foreign trade and commerce. Thus while analysing Vattel's work for discerning the classical principles of international investment law, the terms and phrases like foreign wealth, foreign trade, wealth of foreign nationals etc. shall be understood to cover foreign investment in broad conceptual sense on the premise that the contemporary form of flow of foreign investments are a kind of advanced, specialised and thus distinct form of the foreign trade and foreign commerce then during the days of Vattel. Thus the customary principles of law as applicable to the foreign trade, foreign wealth or foreign commerce then may be extrapolated to discern the foundational principles of the classical international investment law on the protection of foreign investments. Further the body of contemporary international law on foreign investments has not been made over a day, it has evolved with the evolution of the foreign commerce in the annals of the history, and so, the closest historical seedling of the contemporary international investment law may be found in the principles of the classical international laws for the foreign commerce and foreign wealth.

The validity of these premises may be ascertained in the works of Vattel as well. Thus under Section 97 of Chapter VIII of Book I on the subject entitled "Of Commerce", while referring to grant of exclusive privileges by a sovereign nation to a foreign national refers to grant of privileges for manufacture, which by its very nature is a kind of grant of privilege for foreign investment. As a matter of abundant caution, it may be stated that it's not that during the days of Vattel, commercial activities akin to contemporary process of foreign investments, did not exist. There did exit cases where the foreign nationals from one country obtained privileges to own, establish and commercially run factories, ports, and even fortresses and garrisons in alien countries. Vattel makes specific reference to such kinds of privileges obtained by Europeans from various sovereigns in India and other East Asian countries then in the seventeenth century (See Section 89, Book II, Vattel, 2008 (1758)). However, given the rare instances of such activities, where the foreign nationals of one country may have obtained privileges from the sovereigns of other country to run factory, ports etc., it is understandable that a distinct branch of International Investment Law, so complex and vivid, as it is now, did not develop.

On careful consideration of the contemporary International Investment Law, 
one may find that this subject broadly deals with the issues like legal ability of the foreign investors to invest in other countries, the treatment of foreign investors in foreign countries, the remedies available with the foreign investors in case of injury and damages to their person and property by expropriation and other methods, right of the home state to intervene in cases of denial of justice to their national-investors in foreign countries and lastly the settlement of disputes between the home state and host state by peaceful and other methods like use of force. The present paper seeks to capture these issues of the contemporary International Investment Law from the theses of Vattel's Law of Nations written in the mid of the eighteenth century.

Vattel has used the terms "sovereign, state, nation, country and prince," in their distinct connotations as understood then; however in the present analysis all these terms have been used interchangeably to connote a nation or a state possessed of sovereignty.

\section{Discerning Analysis}

Vattel's work is divided in four different parts, each part being called book; the first book in on the subject titled "Of Nations considered in themselves", second book is on the subject titled "Of a Nation considered in its Relation to others", the third on the subject "Of war" and the fourth book on subject titled "Of the Restoration of peace and; and of embassies". As the contemporary issues of International Investment Law has various dimensions touching almost every aspect of international law, all the four books of Vattel has been studied to identify and analyse all such theses which relate to one or other aspect of contemporary international investment law. Such identified theses relating to one or other aspect of contemporary issues of international investment law can broadly be structured under the following sub heads.

\section{1) Foundation of the right of commerce between different nations}

Commerce between the nations is central to the very idea of foreign investment. Flow of investment from one country to other can occur only when the commercial relationships between two nations have natured to the level of adequate confidence between the two nations and their people to let the things of value like capital flow across the boundaries. In respect of the foreign trade which in the contemporary context includes foreign investments, Vattel asserts that "a nation is obliged to promote and carry on a foreign trade" for the welfare of the state as well as for the welfare of the citizens. (Section 87, Book I). Taking a much broader context and perspective of foreign trade, Vattel considers it necessary for the whole human race and thus reiterates that “... nations, as well as individuals, are obliged to trade together for the common benefit of the human race, because mankind stand in need of each other's assistance." (Section 94, Book I). These obligations of the state as well as for the individuals to do foreign trade emanate from fundamental considerations which Vattel refers as collectively constituting "foundation of the right of commerce between different 
nations". These fundamental considerations are; first, under the laws of nature, "( $\mathrm{m})$ en are obliged mutually to assist each other as much as possible, and to contribute to the perfection and happiness of their fellow-creatures." (Section 10, Preliminaries). Second, "no one can by any other means procure the different things that may be necessary or useful to him, and calculated to render life pleasant and agreeable" (Section 88, Book I). Third, "since right springs from obligation ... every man has the right of procuring the things he wants, by purchasing them at a reasonable price from those who have themselves no occasion for them" (Section 88, Book I). Fourth "that men could not free themselves from the authority of the laws of nature by uniting in civil society, and that the whole nation remains equally subject to those laws in its national capacity; so that the natural and necessary law of nations is no other than the law of nature properly applied to nations or sovereign states" (Section 88, Book I). From all this, it follows "that a nation has a right to procure, at an equitable price, whatever articles it wants, by purchasing them of other nations who have no occasion for them. This is the foundation of the right of commerce between different nations, and, in particular, of the right of buying" (Section 88, Book I). Accordingly, it is general duty of the sovereign nations towards the humanity to promote and encourage trade including foreign trade with other nations.

\section{2) Foreigners' Right to trade in Other Country: An imperfect Right}

What kind of rights to the foreign investors have to invest in an alien nation? In the Vattel's thesis the foreigner's right to do commerce, which in the contemporary context would include foreigner's right to invest in a foreign territory is subject to will, conditions and regulations of the sovereign of the foreign territory. In Vattel's framework of the Law of Nations, the duty of self-preservation is one of the perfect obligations of a state and so anything that may prejudice the preservation of the state has the power to regulate it. Thus every nation has the liberty to assess for itself whether the foreign commerce is dangerous to the state and in such cases to renounce and prohibit it, as her duty to herself is "paramount to ... duty to others" (Section 94, Book I). Thus Vattel asserts that the obligation to promote foreign trade is without prejudice to "the will of any nation to carry on commerce with another, or to let it alone" (Section 92, Book I). Wherever the nation grants rights to trade to a foreigner trader, it is unto the will of nation "to permit it under such conditions as she shall think proper" (Section 92, Book I). Thus describing the nature of right of a foreign trader as a "no-perfect right" Vattel notes that, "a simple permission to carry on commerce with a nation gives no perfect right to that commerce" ... as the nation granting such permission is ... "at liberty, whenever she thinks proper, to prohibit that commerce,-to restrain it,-to subject it to certain regulations" (Section 94, Book I). Taking note of the treaties which allowed relatively unbridled right of foreign trade on mutual basis between the traders of two or more nations, Vattel contends that a perfect right to foreign commerce may be accomplished by entering into agreement or treaty, in which case, the "treaty that gives the right of 
commerce, is the measure and rule of that right" (Section 93, Book I). However noting that self-preservation is most fundamental obligation of a state, Vattel observes that the validity and thus continuance of such treaty creating perfect rights of foreign traders even on mutual basis is sanctimonious so long it is not "ruinous to the state and inconsistent with the public safety" (Section 214, Book II).

\section{3) Treatment of foreigners and their assets in the foreign state}

Treatment of foreigner's and their assets in an alien country is one of the critical aspects of the contemporary international investment law. In chapter III of book II Vattel deals with the rules in respect of foreigners when they inhabit a foreign nation. Though these rules have been stipulated with respect to foreigners, however, in the evolutionary context of the international investment law, the term foreigners should be broadly understood to include foreign investors as well.

Vattel reiterates that, it is in the power of the sovereign to "forbid the entrance of his territory either to foreigners in general, or in particular cases, or to certain persons, or for certain particular purposes, according as he may think it advantageous to the state" (Section 94, Book II). Wherever such permission for entry in the territory may have been given, the sovereign is empowered to "annex what conditions he pleases to the permission to enter" (Section 100, Book II). Even where a country allows foreigners to freely enter, there is supposition that sovereign has allowed access upon the tacit condition that the foreigner is subject to the general laws of the nation made to maintain good order (See Section 101, Book II, Vattel, 2008 (1758)). Besides the foreigner is under obligation to bear all such burden which are not exclusively reserved for citizens like the obligation to pay duties imposed upon provisions, merchandise, etc. and such other duties in relation to one's residence in the foreign country and in relation to the affairs which brought him there (See Section 106, Book II, Vattel, 2008 (1758)). These conditions in respect of the foreigners, whether express or tacit flows out of the attributes of the sovereignty of the host state and the laws made by the sovereign of that state. This is so evident when Vattel notes that, "the sovereignty is the right to command in the whole country; and the laws are not simply confined to regulating the conduct of the citizens towards each other, but also determine what is to be observed by all orders of people throughout the whole extent of the state (See Section 101, Book II, Vattel, 2008 (1758)). In respect of the immovable property, Vattel particularly mentions that,

"Every state has the liberty of granting or refusing to foreigners the power of possessing lands or other immovable property within her territory. If she grants them that privilege, all such property, possessed by aliens, remains subject to the jurisdiction and laws of the country, and to the same taxes as other property of the same kind. The authority of the sovereign extends over the whole territory; and it would be absurd to except some parts of it, on account of their being possessed by foreigners" (Section 114, Book II). 
Vattel contends that rights, privileges and possessions acquired by a foreigner in the course of commerce in the alien land are subject to the laws and the powers of the sovereign state. He differentiates between high domain and useful domain. Whereas the high domain is "the body of the nation, or of the sovereign who represents it, is ... considered as inseparable from the sovereignty"; the useful domain is the "the domain confined to the rights that may belong to an individual in the state, may be separated from the sovereignty" (Section 83, Book II). All the acquisitions of the rights and property in any territory of a sovereign state by a private person are the acquisitions of useful domain in the territory without in anyway interfering with the sovereignty of the nation. Similarly, all acquisitions by a foreigner in their individual capacity in a foreign territory, irrespective of the terms of acquisition, can extend only to "the useful domain" in a manner that the high domain or the sovereignty in the said acquisitions remains intact with the sovereign entity of the host state. Even acquisitions by sovereigns of assets, privileges or possessions in their private capacity are no better than acquisition of useful domain. This is evident from the assertion by Vattel that even when "sovereigns have fiefs, and other possessions, in the territories of another prince: in these cases they possess them in the manner of private individuals" (Section 83, Book II). Thus a necessary implication of this private nature of acquisition of rights, privileges, possessions, assets etc. by a foreigner or by a foreign sovereign in a foreign territory is that, all such acquisitions, irrespective of the terms and conditions of acquisition, are restricted to useful domain in a manner that sovereignty of the state continues over the territory unfettered. Thus all the privileges, rights or possessions acquired by a foreign entity over a property situated in a foreign country are governed by the laws and sovereignty of the host state. Only the succession rights of the legal heirs over the property are determined by the laws of the home state of the foreign national (See Section 110, Book II, Vattel, 2008 (1758)).

\section{4) Power of the sovereign state to acquire foreigner's property}

Expropriation and other kinds of taking over of the assets of foreigners is a central issue in contemporary international investment law. Vattel approaches this issue of expropriation of foreigners' assets from the perspective of nature of ownership of such assets qua the sovereignty of the nation states. Like the citizens of the nation, the property rights for foreigners in an alien nation are also limited to the extent of the useful domain only. It does not impact the sovereignty of the state over the property owned by a foreigner. Thus whereas the foreigner may acquire and own private property in a foreign territory, and whereas the sovereign of the state is under obligation to recognise and protect the private property rights of the foreigner, this privilege of the foreigners is without prejudice to the power of eminent domain of the host nation. In exercise of the power of eminent domain, the host state may acquire the private property of a foreigner situated in its state. Vattel describes, eminent domain as the, "right which belongs to the society, or to the sovereign, of disposing, in case of necessity and 
for the public safety, of all the wealth contained in the state" (Section 244, Book I). He justifies the power of eminent domain in following terms,

"Everything in the political society ought to tend to the good of the community; and since even the persons of the citizens are subject to this rule, their property cannot be excepted. The state could not subsist, or constantly administer the public affairs in the most advantageous manner, if it had not a power to dispose occasionally of all kinds of property subject to its authority" (Section 244, Book I).

By its very definition the exercise of the power of eminent domain is restrictive, purposeful and without prejudice to the imperatives of justice. Thus Vattel notes that wherever the property of a private individual or community is acquired by the sovereign in exercise of eminent domain, "justice requires that this community or this individual be indemnified at the public charge ..." (Section 244, Book I). Indemnification for the property acquired by the state is sacrosanct to the exercise of power of eminent domain, firstly because, otherwise, it would become extortion by the sovereign. Secondly, Vattel describes state or nation as a moral person, and it would be contrary to the moralistic nature of the State to deprive one of its private properties without indemnification. Thirdly, appropriation of property of private persons without indemnity tantamount to causing injury to the private person; any such causation of injury by the state is contrary to its obligation to protect people under its sovereignty (See Section 1 of Book I, Vattel, 2008 (1758)). Fourthly, the very institution of the private property, which the state is obligated to preserve, would be under threat by the actions of the state, if it is empowered to appropriate private property without indemnity.

The foreigners inhabiting the state are as much entitled to indemnification, as the citizens are, in case of appropriation of private property by the state in exercise of its power of eminent domain. This is so because the state is under obligation to protect foreigners in similar manner as it is for their own citizens. As a matter of general rule, Vattel notes that, "the state, which ought to respect the rights of other nations, and in general those of all mankind, cannot arrogate to herself any power over the person of a foreigner, who, though he has entered her territory, has not become her subject" (Section 108, Book II). As soon as a nation allows a foreigner to be admitted in his state, "he engages to protect them as his own subjects, and to afford them perfect security, as far as depends on him" (Section 104, Book II). This principle also flows from the fact that, rights of private property are a kind of sine qua none for commercial intercourse, and wherever the commercial intercourse have international dimension, it is imperative for meaningful commercial intercourse between the nations that each nation recognise and protect property rights of foreigner in their territory. In Vattel's scheme of International Law, promotion of international commerce is considered as a sacrosanct obligation of the state, and thus by necessary implication, the recognition and protection of property rights of foreigners would also be an obligation of the state. This obligation of the state is without prejudice to its 
power of the state to punish a foreigner for violating the laws of the state, as the foreigner's entry in the state is subject to either tacit or express willingness to obey the laws of the host state.

\section{5) Obligation of the host state to ensure justice to foreign trader}

Fulfilment of the obligation to ensure substantive justice to foreigner investors is another critical issue of the contemporary international investment law. In Vattel's framework of the international law, the sovereign of the host state is under obligation to ensure that no alien residing in its state suffers wrongs either by its citizens or the government. If an alien has suffered any such wrong, it is obligation of the state of residence to make just reparation to undo the damage suffered. Vattel derives these obligations of the home state for the alien nationals from the need for the very continuance of the mankind on this earth. Thus he that contends that "nations ought mutually to respect each other, to abstain from all offence, from all injury, from all wrong,-in a word, from everything that may be of prejudice to others" (Section 72, Book II). Vattel further reiterates the imperative for refraining from causing damage to other nation or its citizen in much more explicit words and notes:

"If a sovereign, who might keep his subjects within the rules of justice and peace, suffers them to injure a foreign nation either in its body or its members, he does no less injury to that nation, than if he injured it himself. In short, the safety of the state, and that of human society, requires this attention from every sovereign. If you let loose the reins to your subjects against foreign nations, these will behave in the same manner to you; and, instead of that friendly intercourse which nature has established between all men, we shall see nothing but one vast and dreadful scene of plunder between nation and nation" (Section 72, Book II).

If the wrong is caused by the private acts of the citizens of the other nation, such wrongful acts of the private citizens are not imputable to the nation, if the latter does not suffer his subjects to offend other nations or their citizens (See Sections 73 \& 72, Book II, Vattel, 2008 (1758)). Similarly, if the damages have been suffered by the foreign national in the course of legitimate operation of laws of the state of residence, in such cases the latter is not responsible for the damages so suffered because in such cases, the foreign national has already submitted its explicit or tacit consent to abide by the laws of the foreign nation in the course of the conduct of its businesses.

In the course of trade, commerce and business undertaken by a foreigner in an alien state, it is quite natural that it may get entangled in one or more kinds of legal disputes in relation to its person or property. As an incidence of sovereignty, the laws of the host state regulate the resolution of all disputes including the disputes involving the foreigners throughout the whole extent of the state (See Section 101, Book II, Vattel, 2008 (1758)). In respect of the property of the aliens, Vattel specifically notes that "... all such property, possessed by aliens, remains subject to the jurisdiction and laws of the country ..." (Section 114, 
Book II). From these propositions, it is obvious that any dispute, even if it involves a foreigner or his property, it should be adjudicated and resolved as per the laws and legal-juridical processes of the host state. This power of the nation to adjudge and decide on any dispute within its territory emanate from the power of the sovereignty vested in every sovereign state, as well as imperatives of procedural and institutional expediency. In the Vattel's scheme of things, it is the duty of the sovereign to render justice. To this end, it is an obligation of the state to constitute a "body of prudent, honest, and enlightened men to take cognisance of all the disputes that may arise between the citizens" (Section 161, Book I). The Courts of justice so established is "particularly necessary for the decision of all fiscal causes, - that is to say, all the disputes that may arise between the subjects on the one hand, and, on the other, the persons who exert the profitable prerogatives of the prince" (Section 163, Book I). Thus courts of justice constituted in a state is empowered to adjudicate on the cases relating to profitable prerogatives of the prince as well; and the verdict of these court carry authority not because they possess power higher than the Prince or the sovereign but because of the legitimacy and acceptability which the verdict written by the body of prudent, honest and enlightened judges, come to acquire. Thus these courts which have established and institutionalized capability to adjudge on cases of citizens, and even those involving the sovereign himself, it is logical to assume that they are capable to similarly adjudge cases involving foreigners as well. An honest judge is honest only because he is honest in all cases, whether it involves citizens, foreigners or the sovereign himself. Given the institutional distinctiveness which the courts of justice in a sovereign state have or are expected to have, any presumption that, these courts would tend to be biased against foreign nationals or traders, in cases involving them, seem pre-judgmental. Accordingly, as such there is no bar on these courts to adjudge disputes involving foreign nationals or foreigners' assets. Thus as regards adjudication of disputes arising within the domain of the state, Vattel makes no difference between the disputes involving foreigners or citizens. Rather for all disputes on the territory of the state, he envisages that, "any disputes arise in a state respecting the fundamental laws, the public administration, or the rights of the different powers of which it is composed, it belongs to the nation alone to judge and determine them conformably to its political constitution" so much so that if any foreign power "intrude into the domestic concerns of another nation, and attempt to put a constraint on its deliberations" Vattel considers them as doing an injury to the nation (See Sections 36 \& 37, Book I, Vattel, 2008 (1758)). Emphasising the need for the states to accord deference to each other's jurisdiction, he notes that the, "law of nations directs that states should reciprocally pay that kind of deference to each other's jurisdiction, ... as the civil law ordains within the state that every definitive sentence, passed in due form, shall be esteemed just" (Section 350, Book II). He further exhorts that "between nation and nation, the obligation is neither so express nor so extensive: but it cannot be denied, that it is highly conducive to their peace, and conformable to their duties towards human soci- 
ety, to oblige their subjects, in all doubtful cases, and unless where there is a manifest wrong done to them, to submit to the sentences of the foreign tribunals before which their causes have been tried" (Section 350, Book II). It is not that in no case the sovereign of a state should not interfere in the exercise of jurisdiction by other state involving causes of its citizens. The home state may interfere in the causes of its citizens and grant them protection in causes where there is denial of justice either for the reason that the "justice is refused, or palpable and evident injustice done, or rules and forms openly violated, or, finally, an odious distinction made to the prejudice of his subjects, or of foreigners in general" (Section 84, Book II).

6) Concerns of the home state in the situations of denial of justice to its citizens by the host state

What is the role of the home state of the foreign investor, if the latter is denied justice? Within the framework of the traditional international investment law, this issue has given rise to diplomatic protection. Vattel has addressed this issue philosophically and asserts that it is a duty of a sovereign state to ensure that either the nation itself or its citizens do not cause loss, damage or injury to other nations and their citizens. Wherever a nation causes damages to the other nation, or refuses to cause reparation to be made for the damage done by his subject, or to punish the offender, or, finally, to deliver him up, renders itself in some measure an accomplice in the injury, and becomes responsible for it (See Section 77, Book II, Vattel 2008 (1758)). In such cases, the offending nation fails to observe its obligations to cultivate justice towards the other nation. Vattel observes that the imperatives of justice are "more necessary between nations, than between individuals; because injustice produces more dreadful consequences in the quarrels of these powerful bodies politic, and it is more difficult to obtain redress" (Section 63, book II). Thus he concludes that, "all nations are therefore under a strict obligation to cultivate justice towards each other, to observe it scrupulously, and carefully to abstain from everything that may violate it" (Section 64, Book II).

Correspondingly the other nation, with its sacrosanct obligation of self preservation and self-protection, has the right not to "suffer any of her rights to be taken away, or anything which lawfully belongs to her" (Section 65, Book II). Vattel traces the origin of a nation in "an act of association", by which multitude of men come together, entering into engagements with each other, to form a state or a nation, to promote general welfare, to facilitate for them means for supplying all necessities and to protect and defend them (See Section 16, Book I, Vattel, 2008 (1758)). The nation so formed has the fundamental obligations of self-preservation and self-protection, which includes inter alia, the obligation to preserve, to protect and to defend its members. The obligation to protect, preserve and defend the individual members of the state, emanate "in consequence of the very act of association" (Section 17, Book I). Thus Vattel notes that, "If a nation is obliged to preserve itself, it is no less obliged carefully to preserve all its 
members" (Section 17, Book I). Vattel notes that this right is perfect one and it is "accompanied with the right of using force in order to assert it" (Section 66, Book II). He explicitly notes that the offended nation has the right to "obtain a complete reparation, and to employ force for that purpose, if necessary" (Section 51, Book II). Vattel calls such wars undertaken for obtaining justice as offensive wars which are distinct from defensive wars undertaken by the nations in exercise of its right of just defence that involve "use of force against whoever attacks her and her rights" (Section 67, Book II). In order to repress injustices committed by one nation against the other, Vattel even suggests formation of "a confederacy in order to humble and chastise the delinquents" (Section 70, Book II). This right of using force emanate out of necessity to ensure the reign of justice among the nation in their intercourse, be it commercial or otherwise, as "justice is the basis of all society, the sure bond of all commerce. ... Human society ... would be no longer anything but a vast scene of robbery, if no respect were paid to this virtue, which secures to everyone his own" (Section 63, Book II). He further reiterates this in profoundly commendable statement when he notes:

"In vain would nature give us a right to refuse submitting to injustice,- - in vain would she oblige others to be just in their dealings with us, if we could not lawfully make use of force, when they refused to discharge this duty. The just would lie at the mercy of avarice and injustice, and all their rights would soon become useless" (Section 66, Book II).

From the perspective of preservation and protection of members' property, Vattel further reiterates that "even the property of the individuals is in the aggregate, to be considered as the property of the nation, with respect to other states .... She is interested in that property by her obligation to protect all her members" (Section 81, Book II). An immediate consequence of this principle is that "if one nation has a right to any part of the property of another, she has an indiscriminate right to the property of the citizens of the latter nation, until the debt be discharged" (Section 82, Book II). Another consequence of this principle is that a sovereign is under obligation to avenge the wrongs and injury suffered by its citizens in the hands or in the territory of other sovereign. Vattel notes this proposition quite explicitly when he observes that,

"Whoever uses a citizen ill, indirectly offends the state, which is bound to protect this citizen; and the sovereign of the latter should avenge his wrongs, punish the aggressor, and, if possible, oblige him to make full reparation; since otherwise the citizen would not obtain the great end of the civil association, which is safety" (Section 71, Book II).

Thus the sovereign of an aggrieved citizen is under obligation to ensure full reparation for the wrongful damages suffered by the acts of denial of justice committed by the other sovereign. If the reparation is not made, the sovereign is further under obligation to avenge for the wrongs suffered by its nationals.

\section{7) Resolution of disputes between two nations}


If the differences between two nations relating to foreign trade or the foreign investment in the contemporary context of international investment law give rise to dispute, what is the legal framework within which such disputes need to be resolved? Vattel devotes Chapter XVIII of Book II on the modes of terminating disputes between two or more nations. In this Chapter he contends that whereas a nation ought to "care of her own safety and glory forbids her to submit to injuries. But in fulfilling the duty which she owes to herself, she must not forget her duties to others" (Section 323, Book II). Vattel mentions some of the obligations which one nation owe to others like "render to each nation what is her due,- - to leave her in the peaceable enjoyment of her rights, - to repair any damage that she herself may have caused, or any injury she may have done,-to give adequate satisfaction for such injuries as cannot be repaired, and reasonable security against any injury which she has given cause to apprehend." (Section 324 , Book II). The two principles i.e. principle of duty of self-preservation and the duty of respect towards other nations; combined together, furnishes, "the maxims of the law of nations respecting the mode of terminating disputes between different states" (Section 323, Book II). In such cases when two or more nations are involved in dispute, and neither of two is willing to abandon their right or their pretensions, then in such cases, the disputing nations are "bound to try the gentlest methods of terminating their differences" (Section 326, Book II). Vattel enlist a number of methods in order of gentleness which in the same order should find priority for terminating disputes between the nations. These methods in order as stated by Vattel are: first, an amicable accommodation; compromise; the third, mediation; fourth, the arbitration. If any one of the disputing parties does not "accede either to a conference, an accommodation, a compromise, or an arbitration, the other has only the last resource for the defence of himself and his rights, an appeal to the sword; and he has justice on his side in taking up arms against so intractable an adversary" (Section 333, Book II). Thus as a last resort Vattel recommends the use of force to settle disputes, between the nations, if the pacific modes of settlement of disputes fail. Thus reiterates:

"His own advantage, and that of human society, require, that, previous to taking up arms, he should try every pacific mode of obtaining either a reparation of the injury or a just satisfaction, unless there be substantial reasons to dispense with his recurrence to such measures" (Section 338, Book II).

Wars are the ultimate course of destructive action that may be undertaken by one nation against other. Given the destructive potential of wars for all the nations involved in fighting; the rationality requires that such method of assertion of justice be resorted in exceptional situation of last resort when all other means and methods have failed to yield result. Vattel takes notes of this exceptional nature of wars for assertion of justice and argues for its resort only when a nation has "by her constant maxims, and by the whole tenor of her conduct, ... 
evidently proves herself to be actuated by that mischievous disposition" of a general contempt of justice (Section 70, Book II). Even in such cases, if "there is room for the smallest doubt", it should be supposed that “... the injustice of the party that has committed the injury may proceed from error, and not from a general contempt of justice" and in such cases the harsh action of war should be avoided. (Section 70, Book II). Vattel identifies other coercive measures than the war, which may be used by an aggrieved nation against the other in the order of gentleness. Thus he recommends measures as retaliation, retortion, reprisals (See Sections 339, 341 \& 342, Book II, Vattel, 2008 (1758)).

Vattel says that, "If a nation, on an injury done to her, is induced to take up arms, not by the necessity of procuring just reparation, but by a vicious motive, she abuses her right" (Section 31 Book III). Thus to the extent a nation takes up arms to assert just reparation against a state, Vattel recognises it as its right, but once it goes beyond the assertion for just reparation, any further or more use of force, it becomes an abuse of right. Vattel firmly advocates justice in very stages of war, so much so that he justifies use of arms only for establishing the reign of justice. He reiterates this as follows:

"A sovereign ought, in all his quarrels, to entertain a sincere desire of rendering justice and preserving peace. He is bound, before he take up arms, and also after having taken them up, to offer equitable conditions: and then alone he is justifiable in appealing to the sword against an obstinate enemy who refuses to listen to the voice of justice or equity" (Section 336, Book II).

\section{Conclusion}

Promotion of foreign trade and protection of foreign nationals are among the major subject matters of Vattel's work on Law of Nations. Both these subjects, if extrapolated in the contemporary contexts, subsume the elements of foreign investments, and thus principles of law enunciated by Vattel in eighteenth century for promotion of foreign trade and protection of foreign national, are in great measure true for the contemporary international investment law. It is no surprise that many of the contemporary international law institutions for protection of foreign investments like the scope and standards for protection of foreign investments, principles of reparation, exhaustion of local remedies, diplomatic protection, treaty based protection for foreign investments, measures for peaceful and coercive dispute resolution etc. can be discerned from the Vattel's book published in 1758. The genius of Vattel lies in the fact that the legal principles for promotion of foreign trade and protection of foreign national are envisaged as a subset within the broader framework of the principles of the law of nations and the latter is set within the philosophical and referential framework of the natural law principles. Vattel's natural law principles enunciated for the foreign trade can be extrapolated to address almost all contentious issues of contemporary international investment law. Thus from the perspective of the natural law philosophy, Vattel's work seems to be the most vivid source for the natural law 
principles for the contemporary international investment law. These principles have the potential to enrich the contemporary literatures and jurisprudence on international investment law particularly from the perspectives of pragmatic natural law philosophy.

\section{Conflicts of Interest}

The authors declare no conflicts of interest regarding the publication of this paper.

\section{References}

Stapelbroek, K., \& Trampus, A. (Eds.) (2019). The Legacy of Vattel s Droit des gens. Berlin: Springer. https://doi.org/10.1007/978-3-030-23838-4

Van Vollenhoven, C. (1919). Les trois phases du droit des gens. M. Nijhoff.

Vattel, Emer de 2008 (1758). The Law of Nations. Béla Kapossy \& Richard Whatmore (ed. \& intr.). Indianapolis: Liberty Fund. 